\title{
Occult macular dystrophy
}

INSERM

\section{Source}

INSERM. (1999). Orphanet: an online rare disease and orphan drug data base. Occult macular dystrophy. ORPHA:247834

Occult macular dystrophy is a rare, genetic retinal dystrophy disease characterized by bilateral prog ressive decline of visual acuity, due to retinal dysfunction confined only to the macula, associated with normal fundus and fluorescein ang iograms and severly attenuated focal macular and multifocal electroretinog rams. 